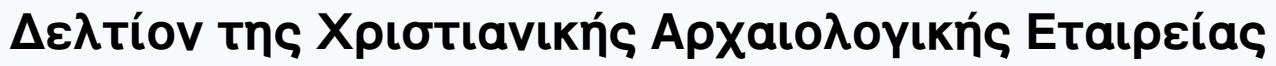

Tóp. 6 (1972)

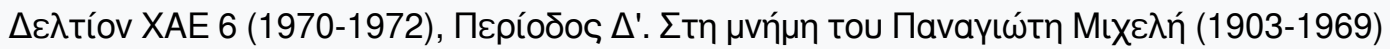

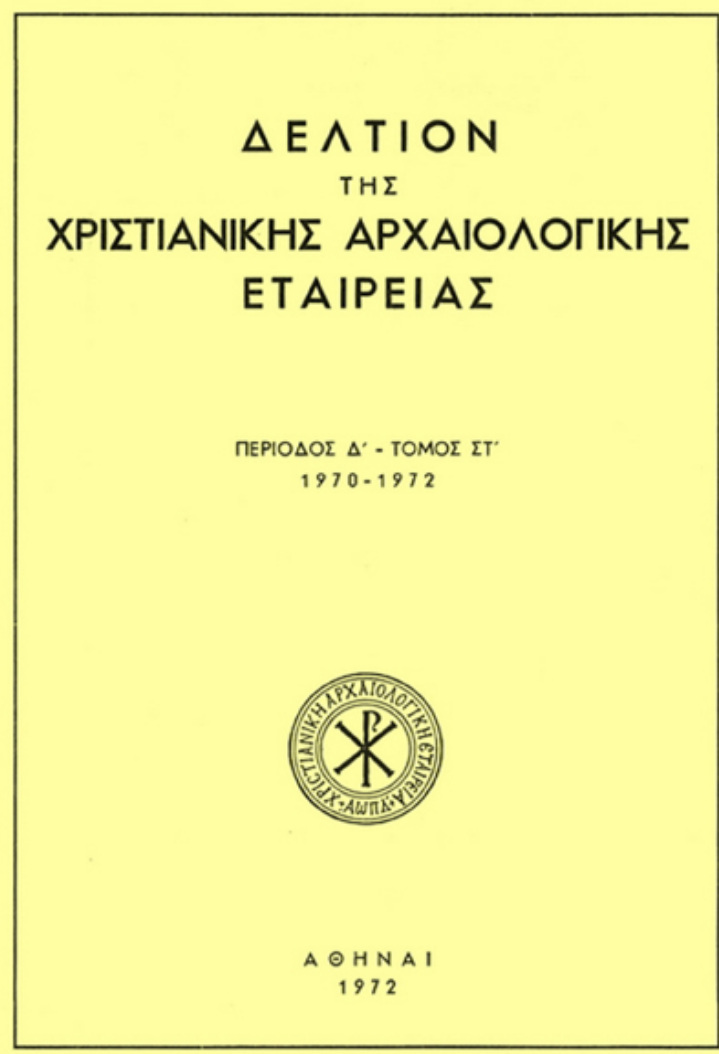

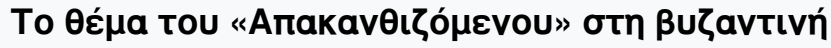

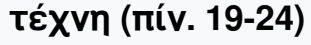

Doula MOURIKI

doi: $\underline{10.12681 / \text { dchae. } 808}$

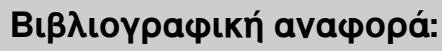

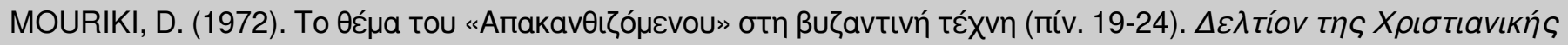

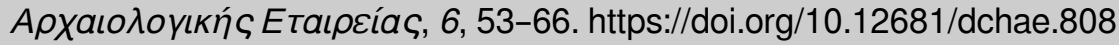




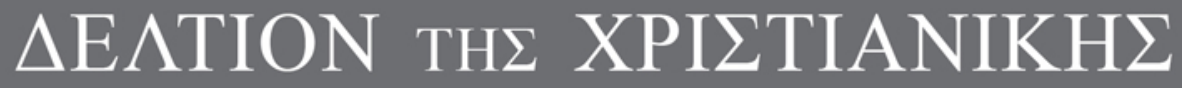 APXAIO $\Lambda$ OГIKH $\Sigma$ ETAIPEIA $\Sigma$}

The Theme of the «Spinario» in Byzantine Art ( 24)

Doula MOURIKI

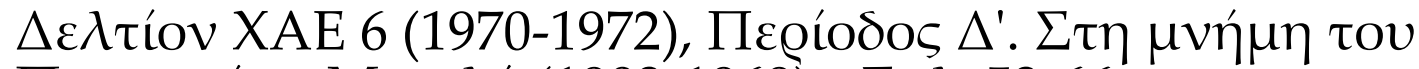

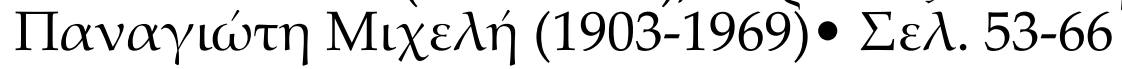

A@HNA 1972 


\section{THE THEME OF THE «SPINARIO» IN BYZANTINE ART}

(PL. 19 - 24)

The figure of a «Spinario» boy on an ivory plaque in Berlin representing the Entry into Jerusalem (Pl. 21) has been often commented on by art historians '. The Berlin ivory has been dated to the tenth century by K. Weitzmann who associated it with the artistic production of the imperial court of Constantinople during the reign of the emperors of the Macedonian dynasty ${ }^{2}$. As a result this theme came to be regarded a classical feature introduced in Byzantine art under the impact of the humanistic movement of the so-called Macedonian Renaissance ${ }^{3}$. After a brief consideration of the history of the "Spinario»", an attempt will be made in the present paper to examine the instances in which the theme appears in Byzantine art and the various forms it assumes, and to indicate the significance it acquires in its new iconographical contexts.

Our concept of the Thorn-Puller or «Spinario" is no doubt derived from the most celebrated example, namely, the bronze statue in the Palazzo dei Conservatori in Rome (Pl. 19a) ${ }^{5}$. There is a great deal of controversy

1. Cf. G. M ill e t, Recherches sur l'Iconographie de l'Evangile, Paris 1916, p. 264 and fig. 249 (drawing). E. P a n o f s k y, Renaissance and Renascences in Western Art, Stockholm 1960, p. 58 and fig. 23. K. W e it z m a n n, Geistige Grundlagen und Wesen der Makedonischen Renaissance (Arbeitsgemeinschaft für Forschung des Landes NordrheinWestfalen 107), Cologne and Opladen 1963, p. 38 and fig. 33; this study was reprinted in an English translation in : K. W e i t z m a n n, Studies in Classical and Byzantine Manuscript Illumination, Chicago 1971 (cf. p. 208 and fig. 190). Ch. D e l v o y e, L' Art byzantin, Paris 1967, p. 286.

2. A. Goldschmidt and K. Weitzmann, Die byzantinischen Elfenbeinskulpturen des X.-XIII. Jahrhunderts II, Berlin 1934, p. 25 and pl. I, 3.

3. We it z m a n n, Geistige Grundlagen, p. 38.

4. An excellent brief account of the history of the (Spinario") is one by W. S. H e c k s c h e r, (Dornauszieher», Reallexikon zur Deutschen Kunstgeschichte 4, 1958, 289-299 (including earlier bibliography). See also $\mathrm{H}$. L a d e n d o rf, Antikenstudium und Antikenkopie (Abhandlungen der Sächsischen Akademie der Wissenschaften zu Leipzig, Philologisch-historische Klasse, Bd. 46, Heft 2), Berlin 1958 (second edition), p. 20-26 and 179-180.

5. Photograph published with the permission of the Gabinetto Fotografico, Rome. For this work see among other studies: H. St u a r t Jones, A Catalogue of the Ancient Sculptures Preserved in the Municipal Collections of Rome. The Sculptures of the Palazzo dei Conservatori, Oxford 1926, p. 43-47 and pl. 60. W. Fuchs, Der Dornauszieher (Opus Nobile, Heft 8) Bremen 1958. 
as to the date and artistic quality of the Capitoline «Spinario». Some archaeologists consider it a genuinely original work of the fifth or fourth century B.C. and others a pasticcio of the Augustan period ${ }^{6}$. Be that as it may, the statue enjoyed considerable fame and was often copied afterwards ${ }^{7}$.

The version of the naked «Spinario», as depicted in the Capitoline example, has been preserved in other antique copies, such as the so-called Castellani «Spinario» in the British Museum, a marble work whose provenance is from Rome ${ }^{8}$, and the bronze copy from Sparta in the Rothschild Collection 9. Moreover, ancient art provides several other variants of the theme depicting small-scale figures, male or female, youthful or advanced in age. Of especial interest, in the context of this study, is a variant consisting of two figures, instead of one : a Satyr in the act of being assisted by Pan to extract a thorn from his foot. Similar examples are found in the Museum at Ostia, in the Louvre and in the Vatican (Pl. 20a), whereas reliefs depicting this group are encountered on Roman sarcophagi ${ }^{10}$. In general, all these specimens fall within the category of genre which enjoyed considerable popularity from the Hellenistic period onwards ". This interpretation is, however, hardly credible if the archetype actually goes back to the fifth century B.C., and scholars who assign the Capitoline «Spinario» to this date have looked for an explanation in history and mythology ${ }^{12}$.

The theme of the Spinario» became very popular in Western art during the Middle Ages $^{1 .}$. One of the explanations for this may be found in

6. Stuart Jones, A Catalogue of the Ancient Sculptures, p. 43-47. See also Enciclopedia dell' Arte Antica VII, 1966, p. 453.

7. L a d e n d o rf, Antikenstudium, p. 25-26.

8. E. Curtius, Brunnenfiguren, Archäologische Zeitung 37, 1879, p. 21-22. A. H. S m it h, British Museum. A Catalogue of Sculpture in the Department of Greek and Roman Antiquities III, London 1904, No. 1755, p. 108-110, pl. VIII.

9. J. d e Wit t e, Le tireur d'épine. Bronze de E. de Rothschild, Gazette Archéologique 7, 1881-1882, p. 127-131 and pls. 9-11. O. R a y e t, Monuments de l'art antique I, Paris 1884, No. 35 .

10. Pl. 20a after M a rgarete Bieber, The Sculpture of the Hellenistic Age, New York 1955, fig. 635. For the examples in Ostia and in the Louvre see ibid., p. 148 and figs. 633-634. For the group on Roman sarcophagi which depicts a Satyr in the act of extracting a thorn from Pan's foot see W. H el b i g, in Bulletin de l' Institut de Correspondance Archéologique, 1880, p. 28.

11. An interesting group of small-scale versions of the (Spinario» is found among the terra cotta figurines from Priene. See T. W i e g a n d and H. S ch ra de r, Priene, Berlin 1904, p. 357 and figs. 434-435.

12. Cf. Stuart Jones, A Catalogue of the Ancient Sculptures, p. 46-47.

13. Among the studies including the history of the "Spinario» in Western art of the Middle Ages especial attention is drawn to J. A dhé ma r, Influences antiques dans 
the fact that the Capitoline statue was almost certainly on view in the Piazza Lateranense, in front of the Papal Palace : a fact that can be deduced from the twelfth century Description of Rome by Magister Gregorius ${ }^{14}$. The relevant passage reads as follows:

Est etiam aliud eneum simulacrum valde ridiculosum quod Pria[pum] dicunt. Qui demisso capite velud spinam calcatam educturus de pede, asperam lesionem pacientis speciem representat. Cui si demisso capite velut quid agat exploraturus suspexeris, mire magnitudinis virilia videbis ${ }^{13}$.

Although the Lateran Palace is not mentioned in this passage, the manner in which the "Spinario» is introduced-Est etiam aliud eneum simulacrum-immediately after the account of the ancient works which were certainly situated ante palatium domini pape, indicates that the statue of the Thorn-Puller was placed in the same locality, and, like the other works, probably crowned a column ${ }^{16}$. If it were not for this account, the only extant information regarding the provenance of the Capitoline «Spinario» would have been that in which we learn that it formed part of the donation of Pope Sixtus IV to the Conservatori in $1471^{17}$.

Magister Gregorius' remark regarding the supposed affinities between the «Spinario» and Priapus is certainly unfounded. This association, which may have been suggested to the mediaeval traveller by local inhabitants, does, however, give us an idea of the contemporary attitude to the ancient work $^{18}$. It has been pointed out that in Western mediaeval art the «Spinario» far from represented a playful genre theme as it did in its ancient antecedents. Among various symbolic interpretations assigned to the figure were those of «luxuria» and idolatry ${ }^{19}$. The theme occurs in various contexts ${ }^{20}$. A specific symbolism in at least some of these instances may, however, be denied with assurance.

l'art du moyen-âge français (Studies of the Warburg Institute 7), London 1939 (reprinted in 1968), p. 189-192. R. H. L. H a m a n n-M a c Le a n, Antikenstudium in der Kunst des Mittelalters, Marburger Jahrbuch für Kunstwissenschaft 15, 1949 - 1950, p. 205-207.

14. G. $\mathrm{McN}$. R u shforth, Magister Gregorius de Mirabilibus Urbis Romae: A New Description of Rome in the Twelfth Century, Journal of Roman Studies IX, 1919, p. 14-58 (particularly p. 23-24).

15. Ibid., p. 49.

16. Ibid., p. 24.

17. Stuart Jones, A Catalogue of the Ancient Sculptures, p. 47.

18. Cf. L. Pres s o u y re, «Marcius Cornator». Note sur un groupe de représentations médiévales du mois de Mars, Mélanges d'Archéologie et d'Histoire 77, 1965, p. 458.

19. H e cksher, (Dornauszieher», 293.

20. Cf. A d hé mar, Influences antiques, p. 190-192. Ha m a n $\mathrm{n}-\mathrm{M}$ a c Lea $\mathrm{n}$, Antikenstudium, p. $205-207$. 
A survey of the examples of the «Spinario» in Byzantine art provides a different picture, as will be shown presently. It should be stressed that, in so far as we know, there is no literary or other evidence indicating the existence of a statue of the «Spinario» in Constantinople or any other major city of the East during the mediaeval period ${ }^{21}$.

The earliest example of the Byzantine period appears to be represented by a gold medallion forming part of a treasure in the Dumbarton Oaks Collection (Pl. 19b) ${ }^{22}$. The object, assigned to the late sixth century, is thought to be of Constantinopolitan origin ${ }^{23}$. The obverse of the medallion shows the profile bust of an emperor. On the reverse an erect figure of Dionysus, flanked by two Satyrs, is depicted in the act of pouring wine into the mouth of a panther crouching at his feet. The depiction is bordered by a vine scroll which sprouts from two canthari, above and below, with various figures interspersed in the free spaces. The figure on the upper right has been correctly indentified as a representation of the (Spinario"; this figure reflects rather faithfully the version of the ancient statue, as represented by the bronze boy of the Capitoline. On the other hand, at the lower left of the same border appears a group of two figures, which, it has been suggested, may represent the scene of the birth of Dionysus ${ }^{24}$. Closer examination of the theme reveals a naked figure seated with his right leg crossed over his left, while a youthful male companion, seated before him, is trying to pull something out of his foot. The composition closely resembles the two-figure variant of the "Spinario», the resemblance being also revealed in the gestures of the figures ${ }^{25}$. Thus, instead of a birth scene from the Dionysiac cycle, which would be hardly compatible with the genre-like character of the entire decoration of the medallion's border, including putti, birds, and the single «Spinario» already mentioned, the theme under consideration may be interpreted as a variant of the single figure.

Two further examples of the «Spinario» in Byzantine art are connected with the classicistic movement of the Macedonian Renaissance of the tenth

21. The most recent study on ancient statuary in Byzantium and the Byzantine approach to it is by C. M a n g o, Antique Statuary and the Byzantine Beholder, Dumbarton Oaks Papers 17,1963 , p. 55-57; this study includes a bibliography relating to the ancient statues on view in Constantinople at one time or another.

22. Pl. 19b after M.C. R o s s, Catalogue of the Byzantine and Early Mediaeval Antiquities in the Dumbarton Oaks Collection, Vol. 2, Washington D. C. 1965, pl. XCIII. For the object see ibid., No. 179, p. 135. Handbook of the Byzantine Collection. Dumbarton Oaks, Washington D.C. 1967, No. 182, p. 52.

23. R o s s, Catalogue, p. 135.

24. Ibid.

25. Cf. B i e b e r, Sculpture of the Hellenistic Age, figs. 633 - 635. 
century. One of these occurs in the most «classical» of the ivory caskets which have come down to us from the Byzantine period, namely, the Veroli Casket in the Victoria and Albert Museum ${ }^{26}$. One of the panels of the front of the casket shows a putto with a bearded mask and beneath him a second putto who appears to be extracting a thorn from a young woman's foot (Pl. 20b) ${ }^{17}$. Regardless of the various interpretations so far suggested as to the identities of the female figure and her adjacent male companion ${ }^{28}$, it may be maintained that the incident relating to the extraction of the thorn from the woman's foot with the assistance of a putto reflects the erotic elaboration of the «Spinario's» theme during the Hellenistic period ${ }^{2}$.

The «Spinario» is depicted in another ivory of the tenth century, this time in connection with the Entry into Jerusalem, a scene which enjoyed tremendous popularity throughout the Byzantine and post-Byzantine period, since it illustrates one of the major feasts in the Christian calendar. Reference is made to the Berlin ivory, already mentioned in the preceding pages (Pl. 21) ${ }^{30}$. In the foreground, below the hoof of the donkey on which Christ rides into Jerusalem the figure of a child is observed about to remove what was presumably a thorn from his left foot. The figure bears a sufficiently close resemblance to the ancient prototype as reflected in the Capitoline bronze. The main differentiating features are the omission of the rock on which the boy in the ancient bronze is seated and the fact that the child's right hand is not used to remove the thorn but to touch the ground, as if he wanted by means of this gesture to support himself. The latter feature, which characterizes the "Spinario» figure in some further variants of the theme derived from antiquity ${ }^{31}$ (in addition to the exomis worn by the rel-

26. For the Veroli Casket see among other studies: A. Goldschmidt and $\mathrm{K}$. W e i $\mathrm{z}$ m a n n, Die byzantinischen Elfenbeinskulpturen des X. - XIII. Jahrhunderts I, Berlin 1930, p. $30-32$, pl. IX-X. K. W e itzma n n, Greek Mythology in Byzantine Art, Princeton 1951, passim, and illustrations. J. B e ckwith, Victoria and Albert Museum. The Veroli Casket (Museum Monograph, 18), London 1962. E rik a S i m o n, Nonnos und das Elfenbeinkästchen aus Veroli, Jahrbuch des Deutschen Archäologischen Instituts 79, 1964, p. $279-336$.

27. Pl. 20b after B e c kw it h, The Veroli Casket, pl. 9.

28. Cf. S i m o n, Nonnos und das Elfenbeinkästchen aus Veroli, p. $324-330$.

29. Erik a S im on's attempt to attribute a symbolical significance to the theme of the extraction of the thorn in the Veroli Casket does not seem convincing. The author's argumentation is based on pictorial and literary evidence, proper to the West only, and on the Byzantine ivory at Berlin (P1. 21). See ibid., p. 326-327. In so far as the latter is concerned, the interpretation of the "Spinario» figure as an incarnation of idolatry is, as will be presently shown, unacceptable.

30. Photograph by Hirmer.

31. Cf. B i e b e r, Sculpture of the Hellenistic Age, figs. 633- 635. 
evant figure in the Berlin ivory) ${ }^{32}$ indicate that the model followed in this instance is not a copy of the Capitoline bronze but of some other version of the «Spinario».

The inclusion of a copy of the ancient theme in the Berlin ivory conforms with the classicizing flavor of the entire composition, as revealed in the contrapostal stance and in the arm placed in the sling of the himation which characterize several figures ${ }^{33}$, as well as the architectural decoration (acanthus, acroteria etc.).

It has not been possible to trace any further depictions of the «Spinario» within the context of the Entry into Jerusalem which could be dated earlier than the thirteenth century, a period to which may probably be dated a provincial fresco in the church of St. Nicholas at Monemvasia (P1. 22a) ${ }^{34}$. Here the scene includes depictions of both the single «Spinario» and the two-figure variant of the theme. Despite the rough style of the St. Nicholas fresco, the poses of these children appear to reflect faithfully those in the antique versions of the «Spinario».

The theme of the «Spinario» occurs in two depictions of the Entry into Jerusalem at Mistra. One of these belongs to the late fourteenth century frescoes of the Peribleptos. Here the scene includes a large variety of genre features, in accordance with the stylistic tendencies of the Palaeologan period in general and of this Mistra example in particular. A frieze of children in various poses depicted before miniature architectural features thus occupies the foreground of the scene. Notably, the pair of children in the middle reproduces the two-figure variant of the «Spinario» $(\mathrm{Pl} .22 \mathrm{~b})^{3.5}$.

Despite the fact that the Entry into Jerusalem in the Pantanassa frescoes, which are dated to c. 1430, repeats to a large extent the corresponding scene in the Peribleptos, we here have a single figure of the «Spinario» instead of the two-figure variant of the earlier fresco (Pl. 23a) ${ }^{36}$. This feature indicates that the source of inspiration of the painter in the Pantanassa fres-

32. According to some scholars, the ((Spinario)) should be assigned to the repertory of bucolic themes (cf. G. Li p pold, Die Griechische Plastik, Munich 1950, p. 331). This interpretation is supported by the considerable number of depictions of the «Spinario», including various pastoral attributes. See also Gertrud Horst er, Statuen auf Gemmen (Habelts Dissertationsdrucke), Bonn 1970, p. 74 - 75, pl. XV, 3 - 4.

33. We it z m a n n, Geistige Grundlagen, p. 38.

34. Photograph of the Frescoes Archive of the National Research Foundation, Athens.

35. Photograph taken by Mr. F. Zachariou. For a reproduction of the entire scene see G. Mille t, Monuments byzantins de Mistra, Paris 1910, pl. 120.1.

36. P1. 23a after D. T a 1 b ot R ice, Byzantine Painting. The Last Phase, New York 1968, pl. XXXI. 
co was not solely confined to the earlier composition in the Peribleptos. In the Pantanassa depiction of the Entry into Jerusalem the «Spinario», clad in a short, sleeveless tunic, is represented seated on the ground in the act of extracting the thorn from his foot with both hands. A two-figure variant of the antique theme is, moreover, observed in an unpublished fresco depicting the Entry into Jerusalem in the church of the Virgin of Peć in Yugoslavia (c. 1330). Here there is a better grasp of the ancient form, as compared with the two former frescoes.

A single figure of the "Spinario» is also to be found in the scene of the Entry into Jerusalem depicted in another work of the Palaeologan period, namely, the so-called large sakkos of the Metropolitan Photius of Moscow $(1408-1432)^{37}$, a work which no doubt had Constantinopolitan affiliations ${ }^{38}$, as was the case in most of the Byzantine examples under review. Similar works from Byzantium may have contributed to further expansion of the ancient motif in Russian art. The theme is depicted, for instance, in two icons of the Novgorod School representing the Entry into Jerusalem ${ }^{39}$.

In the context of this scene the «Spinario» occurs in a considerable number of icons of the Cretan School. Among these is the well-known icon representing a Deesis, saints and scenes from the Dodecaorton at Sarajevo, painted by Nicholas Ritzos ${ }^{\circ 0}$. A single «Spinario» figure is also found in an icon forming part of a Dodecaorton group which used to decorate the sixteenth century iconostasis of the Catholicon of the Grand Lavra on Mount Athos (P1. 24b) ${ }^{\prime 1}$; this Dodecaorton series has been recently attributed, on stylistic grounds, to Theophanes the Cretan, the leader of the Cretan School ${ }^{42}$. The motif also occurs in an icon in the Canellopoulos Collection in Athens (P1. 23b) ${ }^{13}$, a work which preserves the stylistic devices of the Palaeologan period to such a large degree that it may date from the latter part of the fif-

37. Mil1e t, Recherches, p. 277 and fig. 260 (drawing).

38. Cf. J. B e ckwit h, Early Christian and Byzantine Art (The Pelican History of Art), London 1970, p. 156.

39. K. O n a s c h, Ikonen, Berlin 1961, pls. 53 and 54.

40. V. D j u r i ć, Icônes de Yougoslavie, Belgrad 1961, pl. LXXII.

41. Photograph kindly lent by Mr. M. Chatzidakis. For a reproduction of the icon see H. S k r o b u c ha, Meisterwerke der Ikonenmalerei, Essen 1961, pl. XXVI. M. C h a$\mathrm{tz}$ idakis, Recherches sur le peintre Théophane le Crétois, Dumbarton Oaks Papers $23-24,1969-1970$, fig. 39.

42. Ibid., p. $323-324$.

43. Photograph in the Benaki Museum, lent by the kind offices of Mr. M. Chatzidakis. For a reproduction of the icon see $\mathrm{Chatzidakis}$, Recherches sur le peintre Théophane, fig. 129. 
teenth century ". An icon in the Temple Gallery in London, which is very similar to the one in the Canellopoulos Collection, also includes the «Spinario" ${ }^{45}$. This figure is rendered in an identical fashion in all these later examples, with the boy seated on the ground, his left foot extended, right foot raised, while he is engaged in extracting the thorn with both hands; the figure is always clad in a short tunic.

The variant of the theme including the two figures also occurs in a depiction of the Entry into Jerusalem in the frescoes of the Catholicon of Barlaam at Meteora, which have been considered the work of Frangos Katelanos $(1548){ }^{46}$. In this instance (Pl. 24a) ${ }^{47}$ the grimace on the boy's face indicates an attempt to render the emotional background behind the action. The popularity of the «Spinario» in the context of the Entry into Jerusalem is also reflected by the Hermeneia of Dionysius of Fourna which, in the description of the scene, mentions "children extracting thorns» ${ }^{48}$.

The question that now arises is whether the theme constitutes a specific feature of the scene of the Entry into Jerusalem or whether it also occurs in other religious scenes. In order to provide an answer to the question one has first to examine scenes including depictions of children : mainly the Baptism of the Jews, the Baptism of Christ and, to a lesser degree, the Miracle of the Loaves. Depictions of the two Baptism scenes often include children in poses similar to those in the Entry into Jerusalem, a feature that indicates an indebtedness on both sides ${ }^{49}$. In one specific example representing the Baptism of the Jews in the Jordan in the eleventh century copy of the liturgical Homilies of Gregory at Moscow (State Historical

44. An icon in the Monastery of Dionysiou on Mount Athos which is very similar to the one in the Canellopoulos Collection - cf. Ch a t z i da k is, Recherches sur le peintre Théophane, p. 325 - 326 and fig. 130 (detail) - also includes the «Spinario» motif.

45. 8th Annual Exhibition of Icons (4th June-27th July 1968). Temple Gallery, London, No. 14 (with illustration).

46. M. Chatzidakis, Contribution à l'étude de la peinture post-byzantine, L' Hellénisme Contemporain, Le Cinq-Centième Anniversaire de la Prise de Constantinople, Athens 1953, p. 209.

47. Photograph kindly lent by Mr. P. Lazaridis. For a reproduction see P. L a z a -

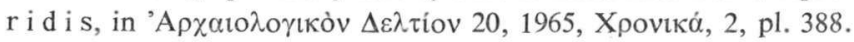

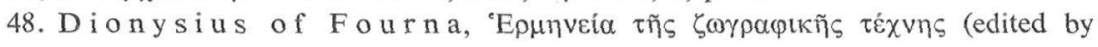
A. Papadopoulos - Kerameus), St. Petersburg 1909, p. 102.

49. Cf. the two boys wrestling on the banks of the Jordan in the baptismal cycle of the mosaics at Kariye Djami (P. U n d e rw o o d, The Kariye Diami, New York 1966, pl. 214) which constitute a frequent feature of the Entry into Jerusalem. On the other hand, the naked boy in the Entry into Jerusalem, as, for instance, in the mosaic of the Cappella Palatina in Palermo (V. L a z a r e v, Storia della pittura bizantina, Turin 1967, fig. 361), is no doubt borrowed from a Baptism scene. 
Museum, Cod. 146) a child is depicted in a pose which closely resembles that of the «Spinario» in the examples which have already been mentioned ${ }^{50}$. In this instance, however, it is not a «Spinario» but a child in the act of taking off its shoes, a motif very appropriate for a Baptism scene. On the other hand, in the scene of the Miracle of the Loaves in the thirteenth century Book of Gospels in the Bibliothèque nationale (Paris. gr. 54) ${ }^{\text {al }}$, occur the two-figure variant of the «Spinario» theme, and a pair of wrestlers, another favorite motif in representations of the Entry into Jerusalem. An explanation for the inclusion of the «Spinario» group may be found in the nature of the landscape setting of the scene which is similar to that of the Entry into Jerusalem. It would seem then that the «Spinario» theme was taken over in the Paris miniature from a representation of the latter scene in which this feature was much more commonly depicted.

Setting aside the existence of the «Spinario» within a secular context, as in the instances of the medallion of the Dumbarton Oaks Collection and the Veroli Casket, it is worthwhile examining the possible significance of this theme in the scene of the Entry into Jerusalem. The question can only be answered after an examination of the reasons that may have motivated the inclusion of children in this scene.

The depiction of children in the scene of the Entry into Jerusalem may derive indirectly from a passage in the Gospel according to St. Matthew which follows immediately after the account of the Lord's triumphal Entry ${ }^{3}$. This passage which refers to the driving of the moneychangers from the temple by Jesus reads as follows:

And when the chief priests and scribes saw the wonderful things that he did, and the children crying in the temple, and saying, Hosanna to the Son of David! they were very displeased.

And said unto him, Hearest thou what they say? And Jesus saith unto them, Yea; have ye never read, Out of the mouth of babes and sucklings thou hast perfected praise? (Matthew, xxi, 15-16).

Even though a justification for the inclusion of children in the scene of the Entry may also be found in the apocryphal gospels ${ }^{53}$, the reference to verse 3 of Psalm viii encountered in the above passage of Matthew consti-

50. Fol. 145. G. G a 1 a va ris, The Hlustrations of the Liturgical Homilies of Gregory Nazianzenus, Princeton 1969, fig. 13.

51. Fol. 55v. La za rev, Storia della pittura bizantina, fig. 386.

52. For the significance of the children in the scene of the Entry into Jerusalem see Millet, Recherches, p. 280-284.

53. Acta Pilati, I, 3. 
tutes the main argument for the presence of the children in this scene. In pictorial art, the association between the Entry into Jerusalem and this verse of Psalm viii occurs in the Rossano Gospels as early as the sixth century. Here, one of the Old Testament figures which point out the typological contents of the scene depicted in the upper part of the page is David represented twice; in one instance his scroll is inscribed with the quotation cited above $^{*}$. Moreover, it is not without significance that this particular verse of Psalm viii was often illustrated with the scene of the Entry into Jerusalem in the Psalters. This applies to both recensions, as shown, on the one hand, by the Barberini gr. 372 of the Vatican Library of the year $1092^{\circ 5}$ and, on the other, by the eleventh-twelfth century Vatopedi 760 on Mount Athos ${ }^{56}$. An interesting example illustrating the same idea is observed in a depiction of the Entry into Jerusalem in the liturgical scroll of the Greek Patriarchate in Jerusalem (Stavrou 109) of the eleventh century where all the welcoming figures are children ${ }^{57}$.

In addition to the pictorial evidence derived from these liturgical texts, the importance attached to the participation of children in the triumphal Entry of Christ is also attested by various texts. For instance, in Etheria's itinerary in the East she tells us that on the anniversary of the historical event on Palm Sunday it is re-enacted by a procession in which the bishop riding an ass advances towards Jerusalem while being acclaimed by a crowd of adults and small children ${ }^{38}$. Of especial interest is also the hymnology of the relevant feast which refers to the children as the only acclaiming figures in the course of the triumphal Entry of Christ ${ }^{59}$. A similar picture is offered, moreover, by the homiletical texts as far back as the early Christian period ${ }^{60}$. Thus a Homily on Palm Sunday by Cyril of Alexandria turns out to be a

54. Fol. 1v. A. M u n o z, Il Codice Purpureo di Rossano e il Frammento Sinopense, Rome 1907, pl. II.

55. Millet, Recherches, fig. 242. The sole inscription of the miniature is : $\tau \dot{\alpha}$ ví $\pi 1 \alpha$

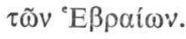

56. K. We itzmann, Aristocratic Psalter and Lectionary, Record of the Art Museum, Princeton University XIX, 1960, p. 105 and fig. 3. The inclusion of a figure of David holding an unrolled scroll, on which Psalm viii, 3 is inscribed, recalls the arrangement in the Rossanensis.

57. A. G r a b a r, Un rouleau liturgique constantinopolitain et ses peintures, Dumbarton Oaks Papers 8, 1954, p. 175, 184 and fig. 14.

58. See Ethérie. Journal de Voyage. Texte latin, introduction et traduction de Hélène Pétré (Sources Chrétiennes 21), Paris 1948, 31, 3. I am indebted to Professor Xyngopoulos for calling my attention to this passage.

59. See Triodion, Venice 1850, p. $333 \mathrm{ff}$.

60. Cf. Mill e t, Recherches, p. 281. 
glorification of the innocent infants who recognized the Lord on the occasion of the Entry into Jerusalem, whereas their parents only saw in him their enemy and eventually led him to the Cross ${ }^{61}$. A similar elaboration of the event is found at a later period in Photius' Homily on Palm Sunday and Lazarus :

And when again I behold them (the children) bearing branches, and going forth to meet Christ, forming choirs and spreading out their garments, I rejoice likewise in that I seee children with unconstrained tongue and deed proclaim the King, and at that moment especially it comes upon me to deplore and hate the perversity of the Jews, inasmuch as children are grateful, while their fathers think of murder, and babes speak of God, while old men fight against God ${ }^{62}$.

The Patriarch continues further below :

It is the children who bring their gift of praise so that the story may expose as unfounded any suspicion of insincerity, in the event that some deliberate evil-doer might say that the singers of praise offered their hymn to the Lord with some artifice and in order to curry favour. For the nature of babes knows not how to devise craftiness, nor is it subject to the disease of flattery, but just as the grace of the Spirit sounds in them, so do they proclaim the miracle ${ }^{63}$.

It is evident from the foregoing passages that the inclusion of children in the scene of the Entry into Jerusalem serves a concrete theological purpose. No doubt this is the reason for the depiction of children in the scene from the Early Christian period onwards ${ }^{64}$. The number of infants included therein as well as their individual poses became a question of preference, in accordance with the stylistic tendencies of each particular period. It would seem to me then that the presence of the «Spinario» in this dogmatic and liturgical composition in Byzantine art should be seen in this context.

Despite the fact that the «Spinario» may had acquired pejorative overtones in Western art during the mediaevel period, the same meaning

61. M i g n e, P. G. 77 : In sanctum festum Palmarum, et in pullum asini, 1053, 1056, 1057.

62. The Homilies of Photius, Patriarch of Constantinople. English Translation, Introduction and Commentary by C. M a n g o (Dumbarton Oaks Studies III), Cambridge Mass. 1958, p. $153-154$.

63. Ibid., p. 157.

64. In rare instances, the welcoming figures in the scene consist exclusively of children. See e.g. the liturgical scroll of the Greek Patriarchate in Jerusalem ( $\mathrm{r} \mathrm{rab}$ a r, Un rouleau liturgique, p. 175). 
can hardly be applicable to the depictions of the theme in Byzantine art ${ }^{53}$. More specifically, it is difficult to believe that one of the children in the scene of the Entry into Jerusalem lost its benevolent character and became the incarnation of evil and idolatry, as may have been the case in some of the Western depictions of the "Spinario» which could, to some extent, have originated from the contemporary attitude rowards the Capitoline bronze ${ }^{f 6}$.

It may be recalled that the "Spinario» was observed in a sixth century medallion, the iconography of which derives entirely from antiquity. The re-appearance of the theme in Byzantine art occurs in the revival period of the tenth century and in objects produced in the sophisticated environment of the capital. The theme was again observed in monuments of the Paleologan period which are related with the art of Constantinople and, after the Conquest, in the artistic environment of the Cretan School which reverts to the Palaeologan period for iconographical schemes and stylistic devices. The association of the motif with works of "classical revival» cannot be vitiated by the existence of more provincial examples such as the one in St. Nicholas at Monemvasia. If compositional schemes disseminated far and wide, even more so can individual motifs which may easily and conveniently find their way into the «note-books» of painters.

It may be observed that the ancient form of the "Spinario» was not really grasped by Byzantine artists, especially after the tenth century. This failure, on their part, corresponds to a general attitude towards ancient art, as exemplified in numerous other cases. It should not be overlooked, moreover, that we are not dealing here with instances of direct copies of ancient works. A chain of intermediary links, which inevitably separates the original from the subsequent copies, contributes to a gradual obliteration of the original form. In the particular instance of the «Spinario» theme, it may well be supposed that the carriers of the ancient motif were portable works, such as the medallion of the Dumbarton Oaks Collection or some ivory of a revival period. After all, the «Spinario» had, already during the Roman period, enjoyed considerable popularity as a theme of decoration of small objects, such as gems, lamps etc. The obvious genre-like

65. A contrary view was expressed by Professor W e it z man n in Geistige Grundlagen, p. 38, where the "(Spinario» in the Berlin ivory depicting the Entry into Jerusalem is considered as a symbol of pagan idolatry over which Christ, as Triumphator, is riding roughshod.

66. The symbolic significance of the Western depictions of the "Spinario» was questioned in a recent study by F. S t e i g e rw a 1 d, Der Meister des Grabmals Friedrichs von Wettin und sein Braunschweiger Löwendenkmal, Argo, Festschrift für Kurt Badt, Cologne 1970, p. 130. 
character of most of these depictions (cf. the Roman sapcophagus reliefs) also indicates that the antique theme was introduced in Byzantine art as a pure decorative feature.

The appearance of the «Spinario» in the context of the scene of the Entry into Jerusalem illustrates a particular aspect of the Byzantine attitude towards the classical tradition : a marked tendency to insert classical elements into Christian scenes which are heavily indebted to antique art from the point of view of both their content and composition. This applies particularly to the scene of the Entry into Jerusalem. It has repeatedly been pointed out that the iconography of this scene was influenced by the reception ceremonies of rulers before city gates -the so-called Adventus- as reflected in antique literature and art ${ }^{67}$. It has even been suggested that the presence of numerous children in the depictions of the Entry into Jerusalem owes something to the antique custom of the active participation of schoolchildren in the official receptions of rulers in Hellenistic cities ${ }^{68}$. This may serve as a satisfactory explanation for the reason why many motifs in the Byzantine iconography of Christ's Entry into Jerusalem appear to have antique antecedents, as, for example, an adult figure carrying a child on its arms, across the shoulder or, holding the child by the hand ${ }^{69}$. These constitute permanent elements of the scene from the post-Iconoplast period onwards ${ }^{70}$. During the revival periods of Byzantine art, antique motifs become

67. See, in particular, A. G r a b a r, L' empereur dans l' art byzantin, Paris 1936, p. 235. E. K a n t o r ow i c z, The "King's Advent» and the Enigmatic Panels in the Doors of Santa Sabina, Art Bulletin 26, 1944, especially p. 215-216. For the ceremony of the Imperial Adventus special attention is drawn to A. A $1 \mathrm{f}$ ö $1 \mathrm{~d} \mathrm{i}$, Die Ausgestaltung des monarchischen Zeremoniells am römischen Kaiserhofe, Römische Mitteilungen 49, 1934, p. 88 - 118. G r a b a r, Empereur, passim. K a n t o r ow i c z, The "King's Advent», p. $207-231$. H. P. L' Or a nge, The Adventus Ceremony and the Slaying of Pentheus, as Represented in two Mosaics of about A.D. 300, Late Classical and Mediaeval Studies in Honor of Albert Mathias Friend, Jr., Princeton 1955, especially p. 9-10. G. K o e p p e 1, Profectio und Adventus, Bonner Jahrbücher 169, 1969, p. 130 - 194.

68. Grabar, Empereur, p. 235 note 2. K a n t o rowicz, The «King's Advent», p. 212.

69. See Ca t a 1 o g u e : Kunst der Spätantike im Mittelmeerraum. Berlin, KaiserFriedrich-Museum, 1939, No. 108, p. 40, pl. 28. D u M e s n il d u B u is s o n, Les Peintures de la Synagogue de Doura - Europos, Rome 1939, pl. XV.

70. Cf. Fol. 196v of the Paris Gregory (Paris. gr. 510) of the ninth century. H. Omont, Miniatures des plus anciens manuscrits grecs de la Bibliothèque Nationale du VIe au XIVe siècle, Paris 1929, pl. XXXVIII. 
more frequent. Genre themes, such as wrestling children ${ }^{71}$, infants associated with doll-like architecture ${ }^{72}$, others enjoying the water of a fountain ${ }^{73}$ etc., were added to this scene. The «Spinario» theme is no doubt the most impressive feature bequeathed by antiquity to the scene of the triumphal entry of the King of the Jews into Jerusalem, the royal city.

DOULA MOURIKI

71. The theme of wrestling children occurs frequently on Roman sarcophagi. F. C u m o n t, Recherches sur le symbolisme funéraire des Romains, Paris 1942, passim. Depictions of putti in different wrestling positions are described in reference to the picture of Palaestra and other Imagines of Philostratus the Elder. Cf. C. R. M o r e y, Early Christian Art, Princeton 1953 (second edition), p. 45. In the context of the Entry into Jerusalem, a pair of wrestling children appears, for instance, in the Berolinensis qu. 66, Fol. 65v ( M i 1 $1 \mathrm{e} \mathrm{t}$, Recherches, fig. 244) etc.

72. For depictions of miniature buildings in antique art, see e. g. Kunst der Spätantike $i_{m}$ Mittelmeerraum, pl. 28. In the scene of the Entry into Jerusalem this feature appears $i_{n}$ a tenth century ivory in the Louvre (Goldschmidt and Weitzmann, Elfenbeinskulpturen II, pl. II, 4), in a painted epistylion of the twelfth century on Mt. Sinai (G. and M. S otiri o u, Icônes du Mont Sinai I, Athens 1956, fig. 97), etc. The association of children with minuscule representations of architecture characterizes the Entry scenes in the Peribleptos and Pantanassa, at Mistra, as well as certain depictions of the scene of a later date (cf. the icon in the Canellopoulos Collection).

73. The association of infants with water-scapes has a long tradition in art (cf. the so-called nilotic landscapes). For a depiction of children and fountains see the Entry into Jerusalem in the Pantanassa at Mistra. 


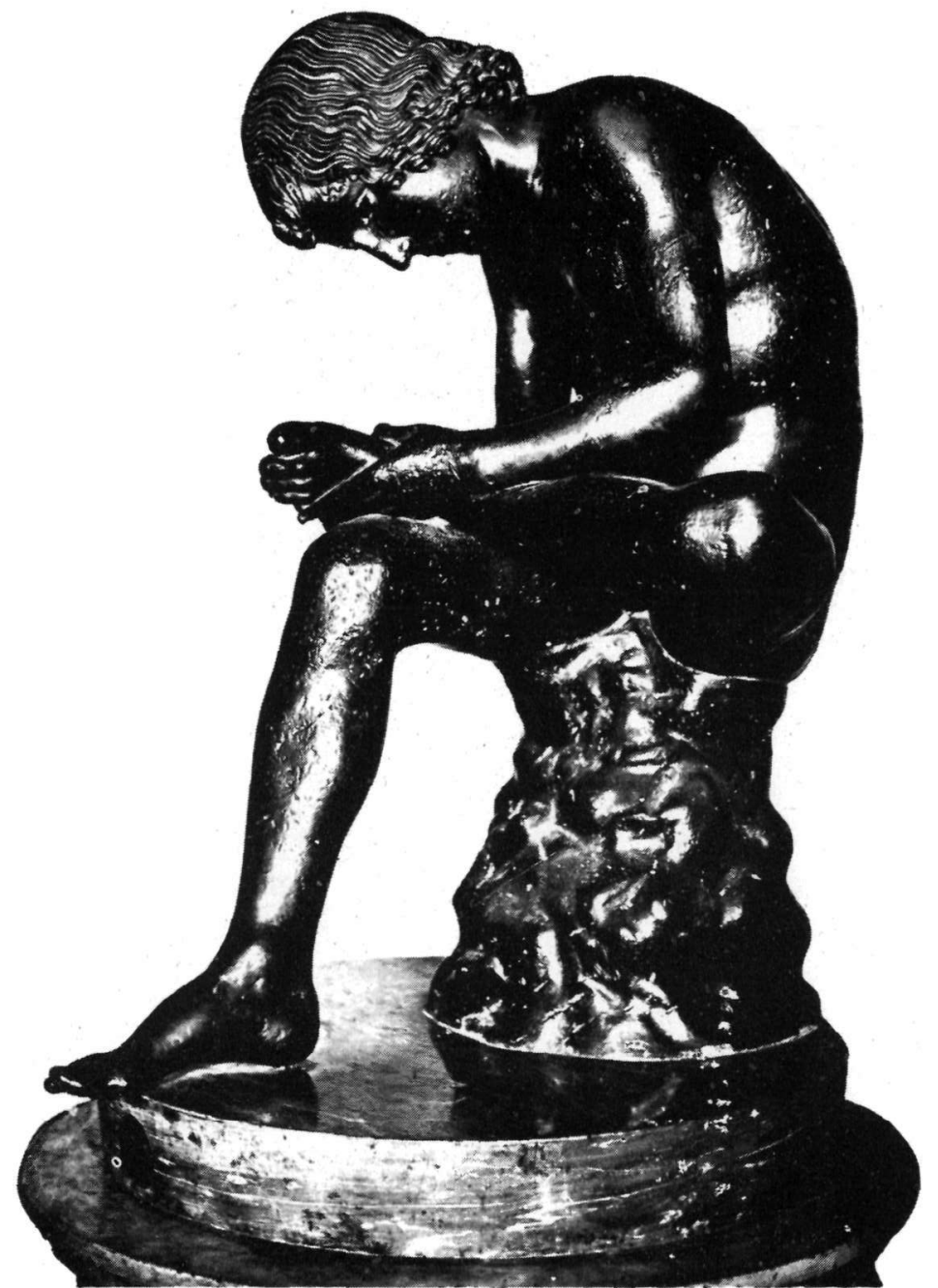

a. «Spinario». Bronze. Palazzo deì Conservatori, Rome.

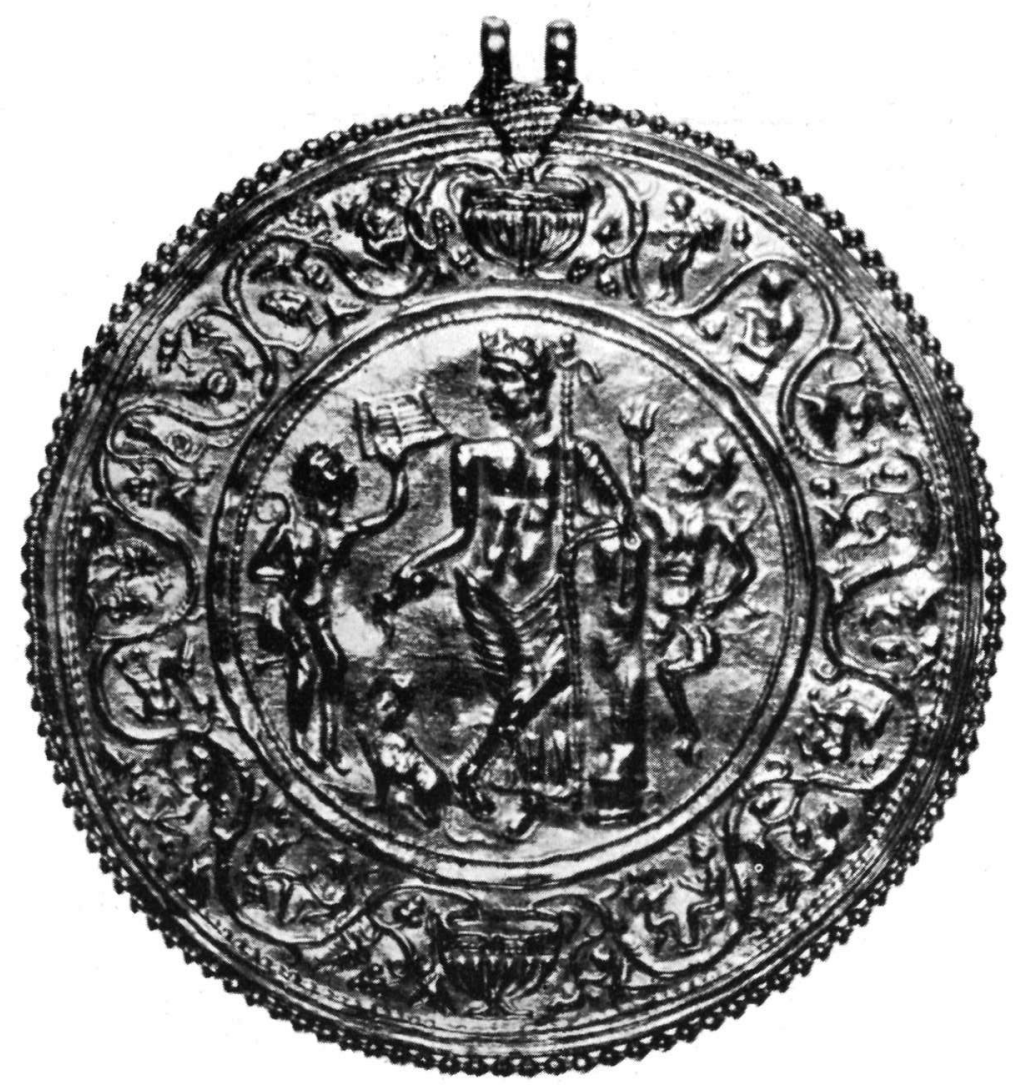

b. Dionysus and genre themes. Gold medallion. Dumbarton Oaks Collection, Washington, D. C. 


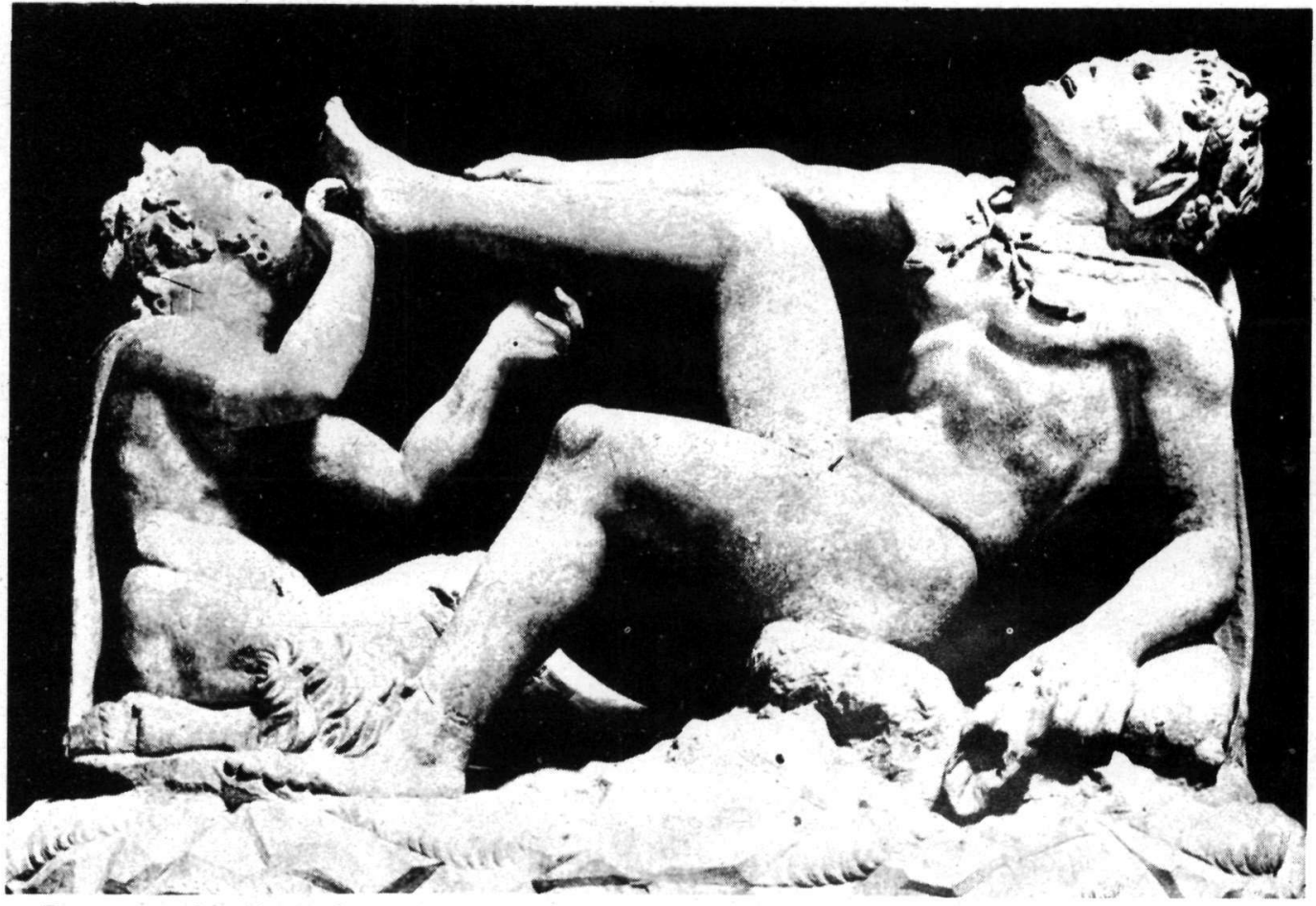

a. Pan extracting thorn from foot of Satyr. Marble. Vatican. Rome.

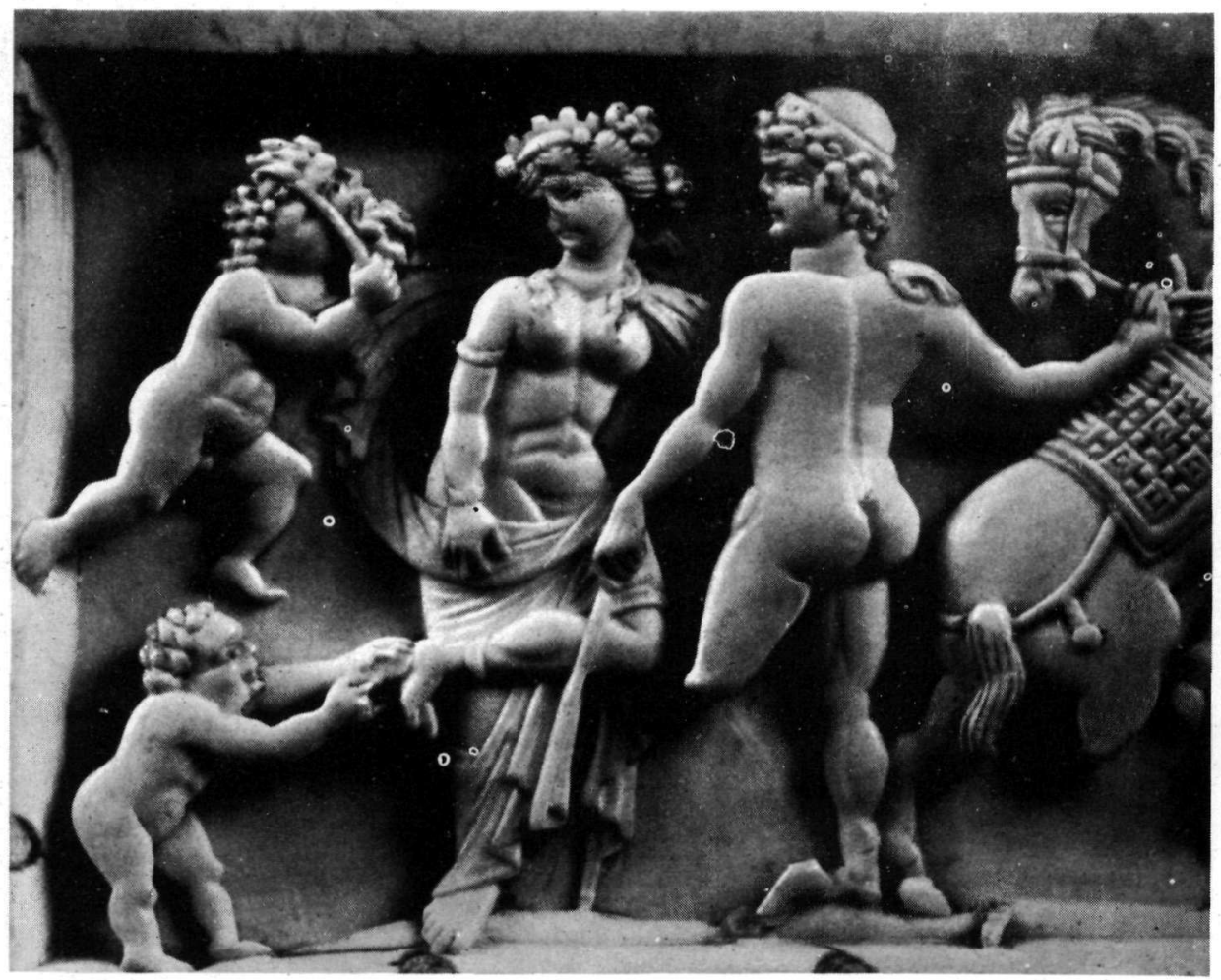

b. Mythological scene on the Veroli Casket. Ivory. Victoria and Albert Museum, London. 


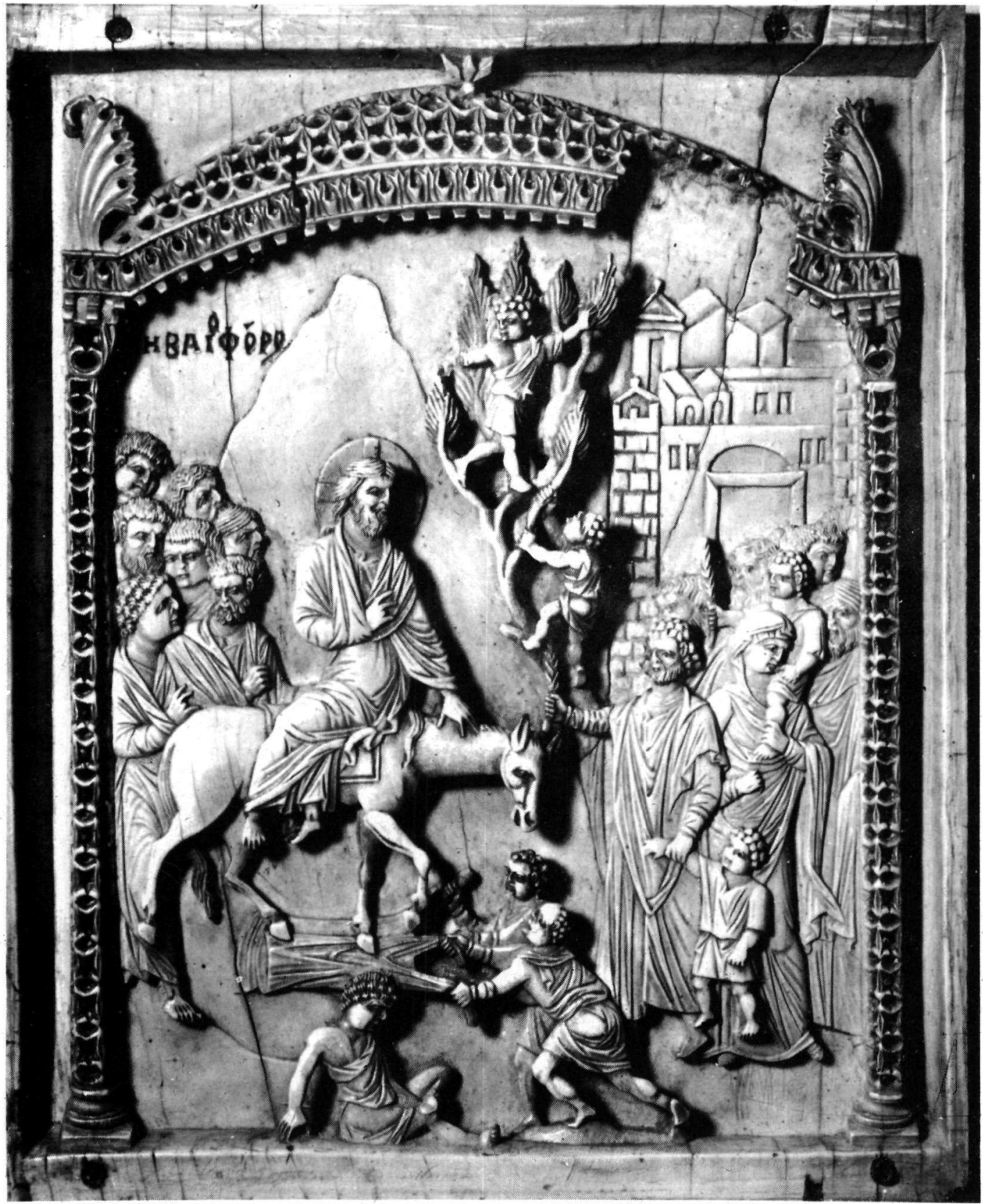

The Entry into Jerusalem. Ivory: Staatliche Museen, Berlin. 


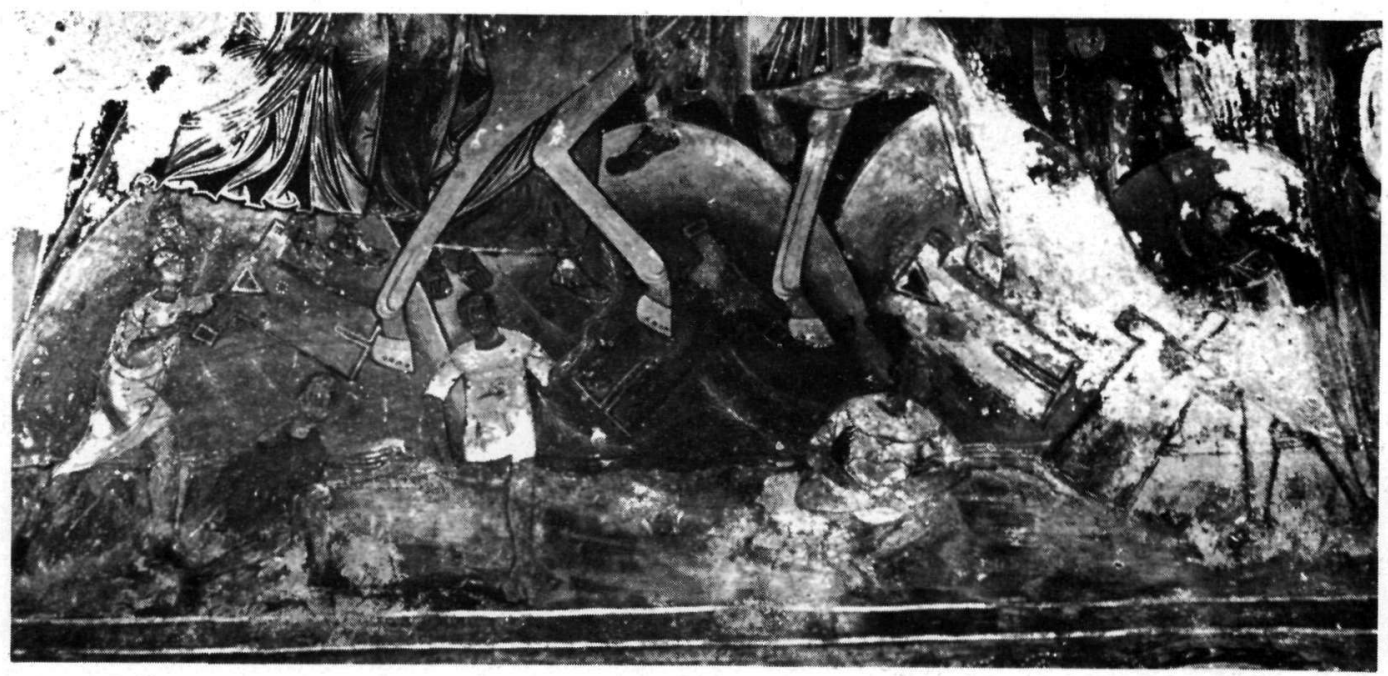

a. The Entry into Jerusalem (detail). Fresco. St. Nicholas at Monemvasia.

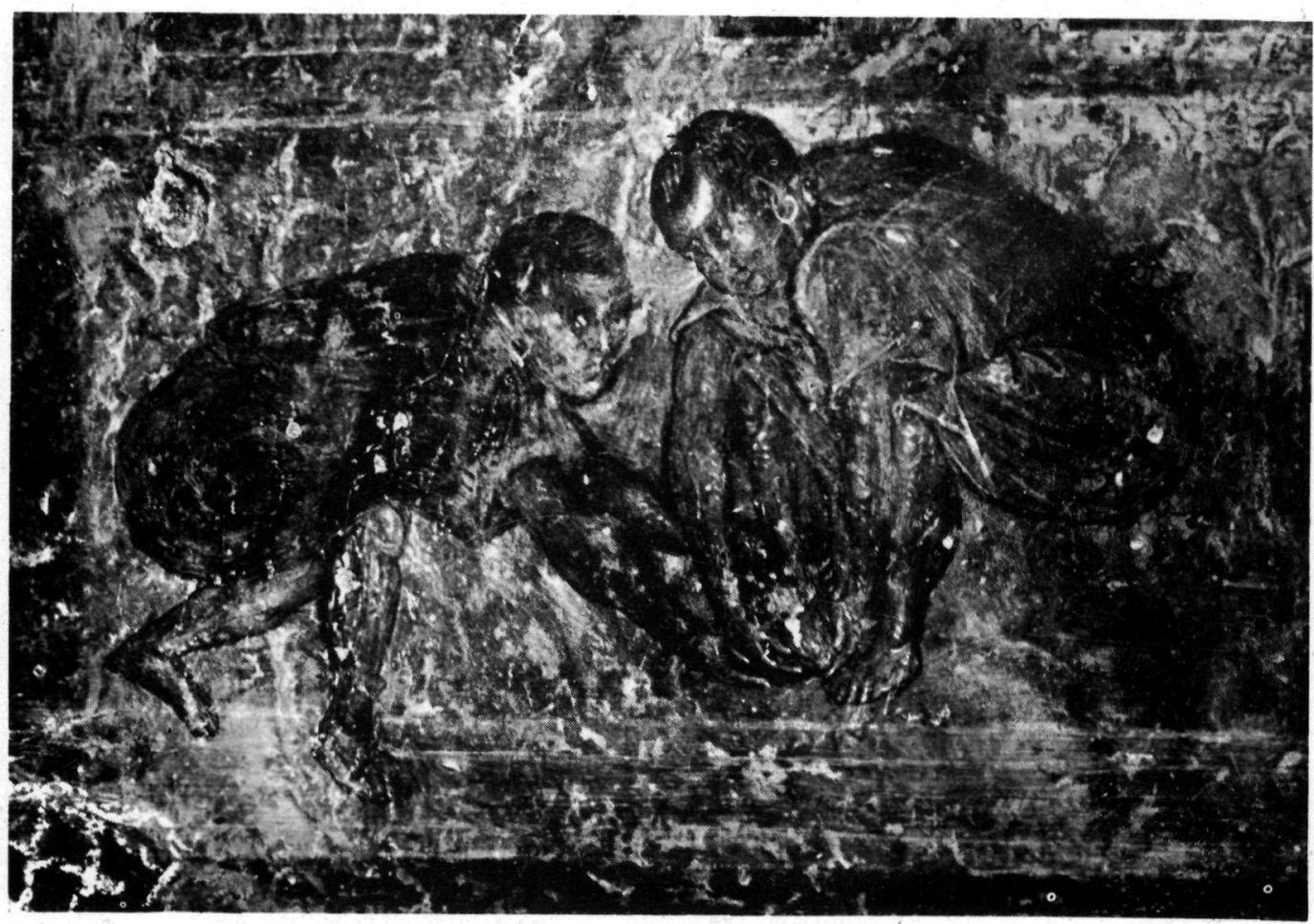

b. The Entry into Jerusalem (detail). Fresco. Peribleptos at Mistra. 


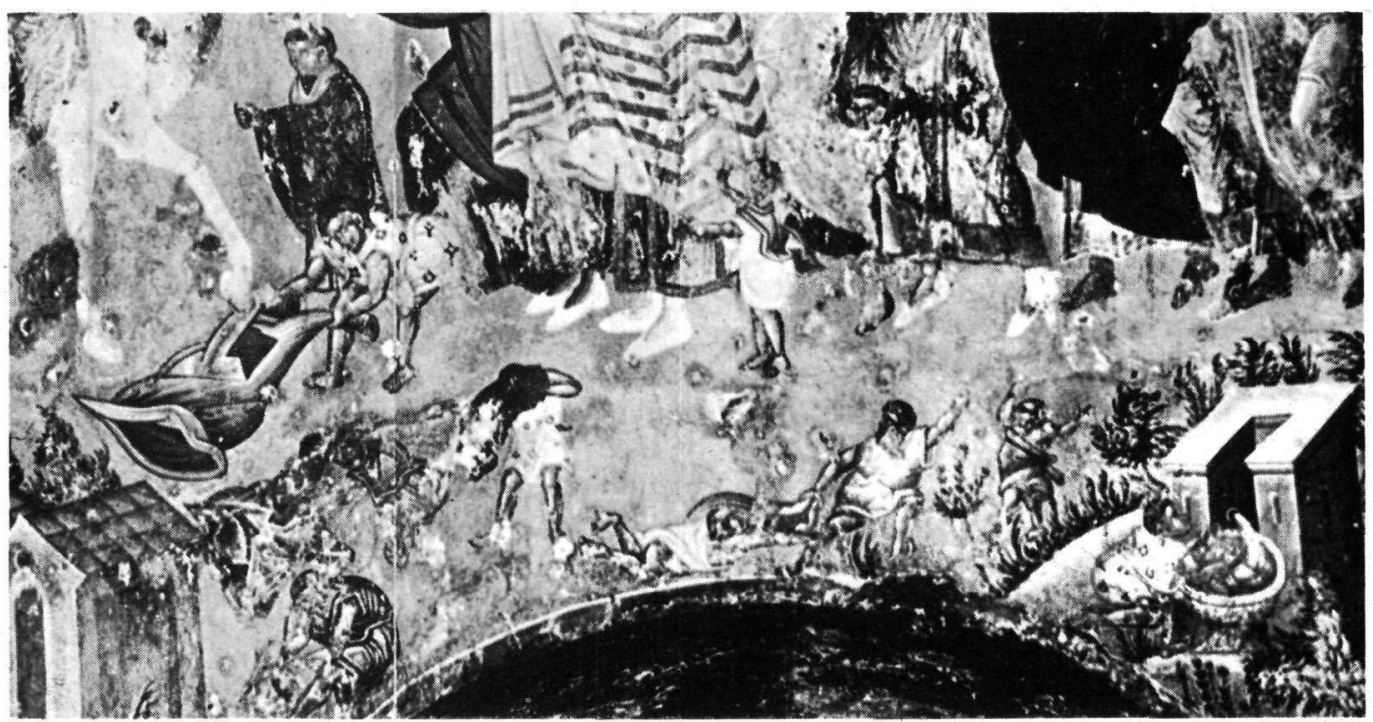

a. The Entry into Jerusalem (detail). Fresco. Pantanassa at Mistra.

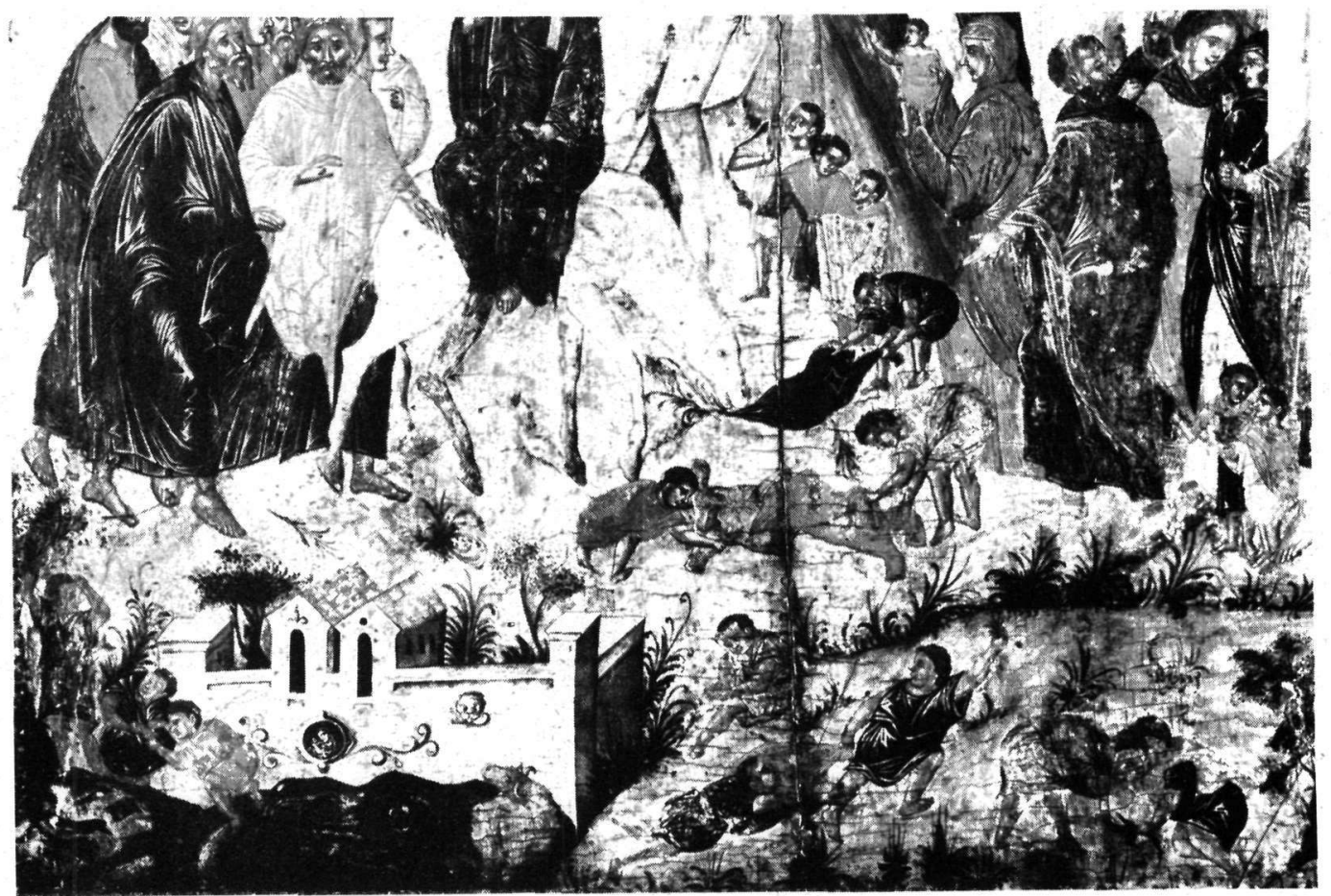

b. The Entry into Jerusalem (detail). Icon. Canellopoulos Collection, Athens. 


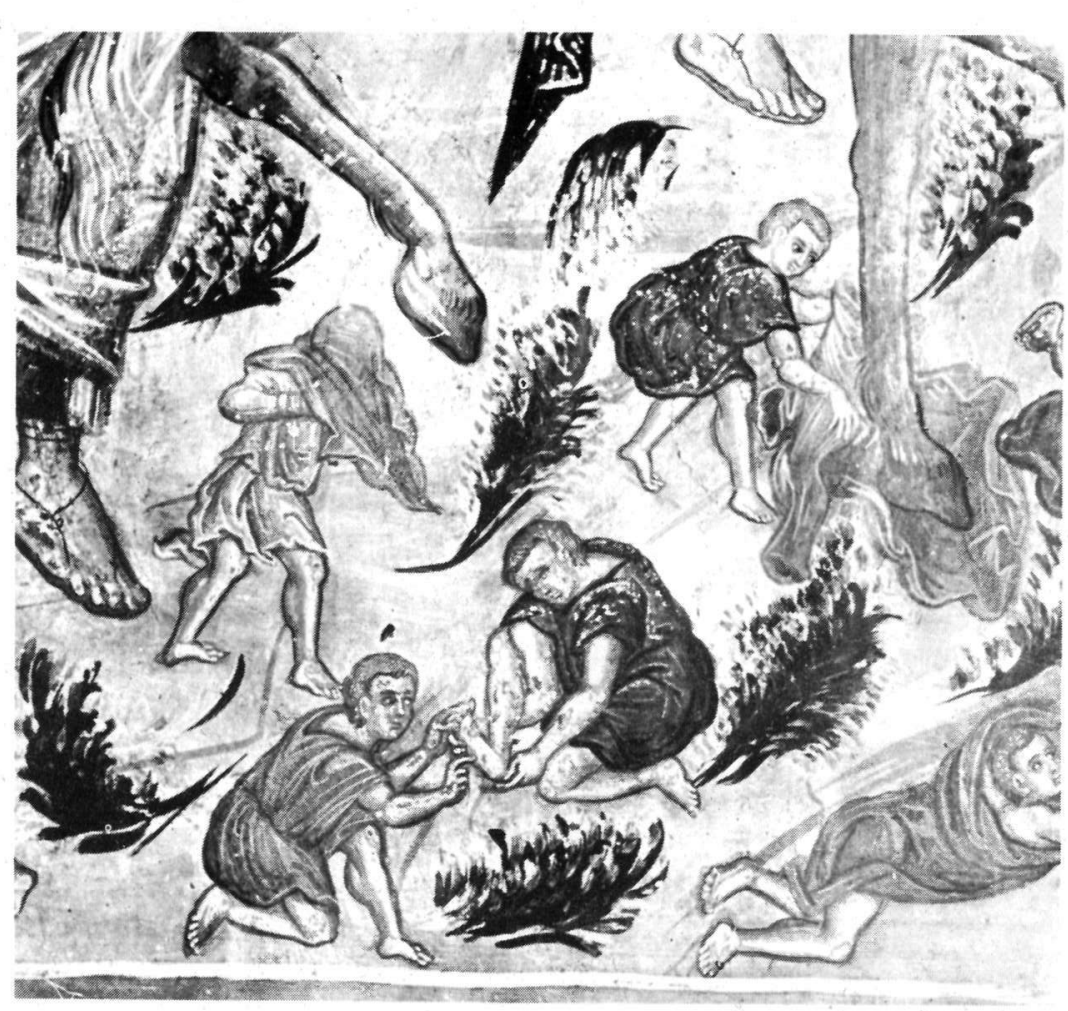

a. The Entry into Jerusalem (detail). Fresco Monastery of Barlaam at Meteora.

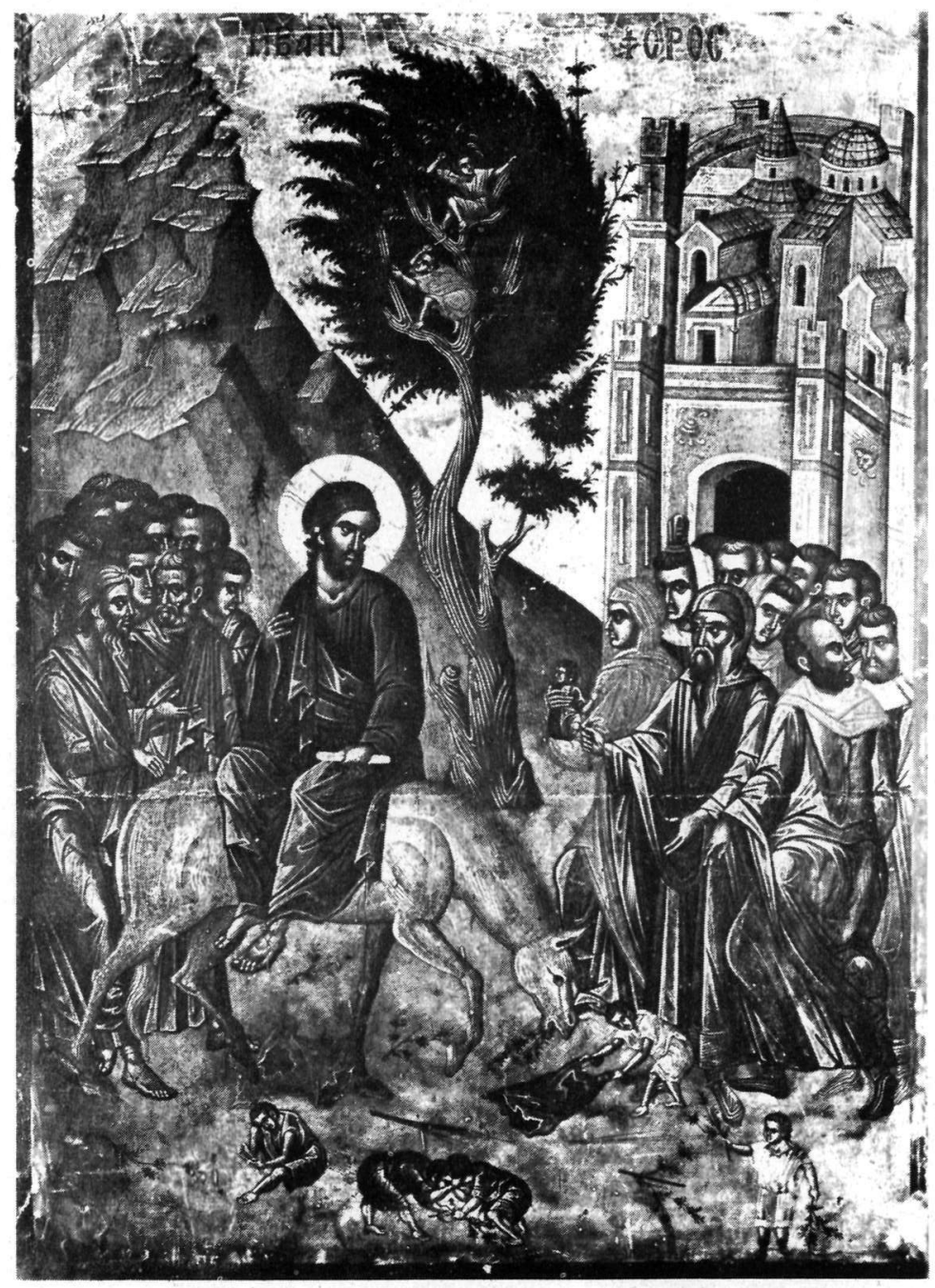

b. The Entry into Jerusalem (detail). Icon. Monastery of the Grand Lavra on Mount Athos. 